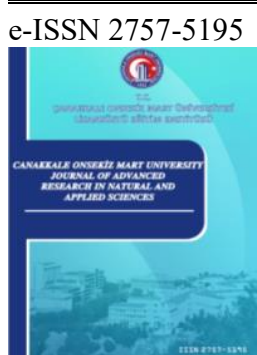

Çanakkale Onsekiz Mart University

Journal of Advanced Research in Natural and Applied Sciences

Open Access

\title{
Estimation of the Climate Preference Between Two Lineages of Euro- pean Ground Squirrel Using Maximum Entropy Modeling
}

\author{
Sadık Demirtaş ${ }^{1, *}$ \\ ${ }^{1}$ Department of Biology, Faculty of Arts and Sciences, Ondokuz Mayıs University, Samsun, Turkey \\ Article History \\ Received: $\quad 28.02 .2020$ \\ Accepted: $\quad 09.10 .2020$ \\ Published: $\quad 29.12 .2020$ \\ Research Article

\begin{abstract}
Spermophilus citellus (Linnaeus, 1766), commonly referred to as the European ground squirrel, exists in specific areas of Central Europe and the Balkans. The species is currently listed as "vulnerable" on the IUCN Red List of Threatened Species. Recently genetic studies have shown that the species has two main lineages; the northern and the southern. The northern lineage shows distribution range at the central and western part of the Balkans and Central Europe, whereas the southern lineage is spread in a more limited area, which includes the southern and eastern parts of the Balkans. The purpose of this study is to reveal the potential geographic distribution in Last Glacial Maximum (approximately $22 \mathrm{kya}$ ), present and future (average 2070) periods of these lineages using Maximum Entropy modeling (MaxEnt). This study also contributes to comparing the distribution of two lineages between past, present and future periods. The final MaxEnt with ten replicate runs was constructed based on 80 occurrence records from Austria, Bulgaria, Czech Republic, Greece, Hungary, Slovakia, Serbia, Macedonia, Moldova, Romania, Turkey and Ukraine, and twelve abiotic bioclimatic variables obtained from WorldClim. Thus, it was attempted to estimate the importance of bioclimatic factors influencing the potential geographical distribution for each lineage as well as assessing the area under curve values. This study showed that the two lineages of the European ground squirrel had different geographic distribution patterns for past, present and future periods. Moreover, the study will make im-
\end{abstract} \\ portant contributions to conservation studies such as management strategies, species action plans and translocation.
}

Keywords - Climatic preference, ecological niche modeling, European ground squirrel, geographic distribution, maxent, jack-knife test

\section{Introduction}

The Quaternary period witnessed many climatic and environmental changes at different stages until today. The current distribution of European species was shaped by the consecution of the glacial and interglacial periods in the Quaternary during which a large part of northern Europe was covered by ice (Hewitt, 2000). A large part of the area above $40^{\circ}$ in Europe was covered by broad terrestrial ice-sheets at a temperature of about $10^{\circ} \mathrm{C}$ lower than today's (Birks \& Willis, 2008). Because of the changing ice sheets and ocean currents, the geographic ranges of the animal species were affected across Europe and Asia especially during the Last Glacial Maximum (LGM) (Peltier, 1994;Pollard \& Thompson, 1997). LGM probably pushed many terrestrial species to survive in refugial areas in the Mediterranean peninsula. It is predicted that the European continent had three classical southern refugia in the Mediterranean (Iberian, Italian and Balkan) which made significant contributions to the re-colonization of northern Europe (Hewitt, 2000; Stewart et al., 2010). From these areas, the Balkan refugial area is undoubtedly the most effective in the re-population of eastern and western parts (Hewitt, 1996; 2000). Moreover, an area called "cryptic northern refugia" has been identified based on fossil and genetic evidence in northern Europe; this refugium had many different ecological characteristics from the South (Stewart \& Lister, 2001; Stewart et al., 2010).

\footnotetext{
1 (iD) sadikd@omu.edu.tr
}

${ }^{*}$ Corresponding Author 
Ecological niche modelings (ENM) are correlative approach methods that are used to predict the distribution of a species or evolutionary lineage across a given geographic area and time using bioclimatic variables or other variables such as soil type and wind speed. These methods are based on the fact that the localities where the species lives are known, the potential distribution area at unsampled locations of that species in the past, present, or future can be inferred by using environmental variables (Peterson et al. 2002; Hijmans \& Graham, 2006; Elith et al., 2011). In recent years, ENM has been widely used in scientific fields such as conservation biology, ecology, phylogeography and evolution (Gür, 2013; Tzvetkov \& Koshev, 2016; Zaharia et al., 2016; Gür et al., 2017; Qiao, Escobar, \& Peterson, 2017). The information obtained from ENM is important for the protection of endangered species and the prevention of habitat loss (Guisan et al., 2013). The Maximum Entropy Algorithm (MaxEnt, Phillips et al., 2004, 2006, 2017a,b) is a presence-background method and is one of the most preferred methods for relating species records to bioclimatic variables (Elith et al., 2011). The algorithm is among the top-performing methods in terms of prediction accuracy and may remain effective despite small sample sizes (Pearson et al., 2006; Elith et al., 2006; Wisz et al., 2008).

Presently the European ground squirrel, Spermophilus citellus is spread from central to south-eastern Europe, but its distribution area is divided into two main geographical areas by the Carpathian Mountains (Kryštufek, 1999; Wilson \& Reeder, 2005; Coroiu et al., 2008; Matějů et al., 2010). Phylogeographic studies focusing on individuals representing a large part of the distribution range of the species indicate that the European ground squirrel has two major genetically independent lineages with seven sublineages (Gündüz et al., 2007; Kryštufek et al., 2009; Říčanová et al., 2013). The northern lineage includes individuals from Austria, Bulgaria, Czech Republic, Slovakia, Hungary, Serbia, Macedonia, Moldova, Romania and Ukraine and the southern lineage consists of individuals from Bulgaria, Greece, Southern Macedonia, Romania and the European part of Turkey (Thrace). These lineages show sympatric distribution within a restricted area in Central and Eastern Bulgaria.

Ŕíčanová et al. (2013) emphasized that the separation time of the northern and southern lineages dates back to the middle Pleistocene period (1.31-1.79 million years ago). Moreover, they proposed possible scenarios based on phylogenetic and biogeographical analyses about the ancestral areas of these lineages. According to these scenarios, Serbia and Macedonia haplotypes represent the oldest $S$. citellus population to the west of the Carpathians. Paleontology also supports the appearance of to the west of the Carpathians in Central and Western Europe in the Gunz glacial of Austria (c. 750 kya, Kurten, 1968). The other haplotypes colonized large areas during several later. The southern lineage originated probably in southeast Bulgaria and first colonized the European part of Turkey. The oldest species record is from the Yarimburgaz Cave in the European part of Turkey and is dated back to 1.323-0.885 Ma (Santel \& von Koenigswald, 1998; Fortelius, 2011). Furthermore, the area around the Carpathian mountains has been a refuge area for many mammalian species (Benda \& Ivanova, 2003; Mráz \& Ronikier, 2016; Savić, Ćirović, \& Bugarski-Stanojević, 2017) and is known to be an important source of genetic diversity, during the Quaternary period (Hewitt, 2000).

Until recently the European ground squirrel occurred in very large numbers in steppe and pasture areas with discontinuous shrubs and trees up to 2,500 m above sea level (Kryštufek \& Vohralík, 2005; Popova et al., 2019). The population size of the European ground squirrel decreased rapidly due to high death rates caused by habitat fragmentation and anthropogenic effects such as agricultural and industrial activities (Zaharia et al., 2016). Today, the population has become fragmented, and even disappeared from peripheral parts of its previous range, as in Germany, Poland and Croatia (Coroiu et al., 2008). Therefore, action plans and reintroduction and conservation projects were prepared in different European countries where the species has been extinct (Balaz, Jancova, \& Ambros, 2008; Matějů et al., 2010; 2012; Gedeon et al., 2011, 2012; Janák, Marhoul, \& Matějů, 2013; Löbbová \& Hapl, 2014; Koshev et al., 2019). As a result, S. citellus has been a protected species within the European legislation under the Bern Convention and EU Habitats and Species Directive. Moreover, 
S. citellus is currently listed as "vulnerable" on the International Union for Conservation of Nature and Natural Resources Red List of Threatened Species (Coroiu et al., 2008).

Recently, ENM, fossil and molecular studies have focused on several ground squirrel species about their likely responses to global climate change (Musil, 1985; Gür, 2013; Říčanová et al. 2013; Gür et al., 2017). In these studies, they were tried to predict the responses of the species to global climate changes during glacial-interglacial cycles. The ENM's results in the past periods suggested that the range limit of S. xanthoprymnus expanded rather than contracted throughout the glacial periods and contracted rather than expanded throughout the interglacial periods (Gür, 2013), contrary to the classical paradigm. Moreover, the results in the present period revealed that annual precipitation and temperature affect the geographical distribution of the species as well as plant productivity. But the $S$. taurensis showed a different geographical displacement. The results demonstrated that the species survived throughout Late Quaternary glacial-interglacial cycles by altitudinal migrations without a large range change movement (Gür et al., 2017). Furthermore, the present analysis result suggested winter temperature and precipitation affect the range limit of the species. These analyses revealed that as warming continues, the potential distribution of species will continue to shift towards higher altitudes, and its range area will be restricted in the future. In another study, the fossil record of S. citellus indicated that it had a wider distribution during the Pleistocene glacial periods than in the interglacial periods (Musil, 1985). Therefore, the current distribution of the species is restricted, which suggests that the European ground squirrel responds to global climatic changes along the oceanic-continental gradient (Stewart et al., 2010). Also, the continental refugia concept has been supported by molecular studies (Říčanová et al. 2013).

ENM can be an effective tool in identifying suitable habitats for the European ground squirrel (Zaharia et al., 2016; Tzvetkov \& Koshev, 2016). Some climate differences observed among the modern geographic distribution of the northern and southern lineages indicate that climate is one of the main determinants of the presence of S. citellus in an area. Therefore, this study aims to find answers to the following questions by using niche analysis based on bioclimatic data.

i) How was the potential distribution of $S$. citellus in central Europe and the Balkans in the Last Glacial Maximum? ii) Is the geographical distribution obtained from ENM of the species throughout the Late Quaternary period compatible with the continental gradient refugia concept, which is also supported by fossil evidence? iii) Which areas were potentially suitable habitats for $S$. citellus lineages? iv) What are the potential distribution areas, bioclimatic variables and their contribution values affecting the distribution of S. citellus today? v) Will the future distribution of $S$. citellus change compared to its current distribution? vi) How will S. citellus adapt to future climate change? vii) Can ENM improve the success rate of reintroduction and conservation projects on S. citellus?

\section{Materials and Methods}

\subsection{Species Data}

Known presence occurrence and translocation records of S. citellus were compiled from different resources including Katona, Váczi, \& Altbäcker (2002); Harrison et al. (2003); Gündüz et al. (2007); Youlatos et al. (2007); Balaz, Jancova, \& Ambros, 2008; Hoffmann, Turrini, \& Brenner (2008); Hulová \& Sedláček (2008); Koshev (2009); Kryštufek et al. (2009); Matějů et al. (2010, 2012); Gedeon et al. (2011), Ŕíčanová et al. (2011, 2013); Haberl, Kryštufek, \& Hoffmann (2012); Baltag et al. (2014); Löbbová \& Hapl (2014); Diakou, Kapantaidakis, \& Youlatos (2015); Barkaszi \& Zagorodniuk (2018); Koshev et al. (2019); the Global Biodiversity Information Facility website (www.gbif.org) and field observations (Figure 1). From these records, locations of molecular-based studies were selected and georeferenced to ensure the precision of the data using Google Earth, version 7.1 (http://www.google.com/earth) and DIVA-GIS, version 7.5 (www.divagis.org) and the data set used in this study was constructed based on the sublineages (northern and southern) 
characterized by mtDNA cytochrome $b$ gene of $S$. citellus. Multiple presence records were spatially filtered and randomly removed within $20 \mathrm{~km}$ distance to correct sampling bias and ensure high geographical heterogeneity (Pearson et al., 2006; Fourcade et al., 2014). Geographic Distance Matrix Generator version 1.2.3 (http:// biodiversityinformatics.amnh.org) was used to calculate the spatial geographic distance among localities. Thus, 59 records for the northern lineage from nine countries (Austria, Bulgaria, Czech Republic, Hungary, Macedonia, Moldova, Romania, Serbia and Slovakia) and 21 records for the southern lineage from five countries (Bulgaria, Greece, Macedonia, Romania and Turkey) were used in this study.

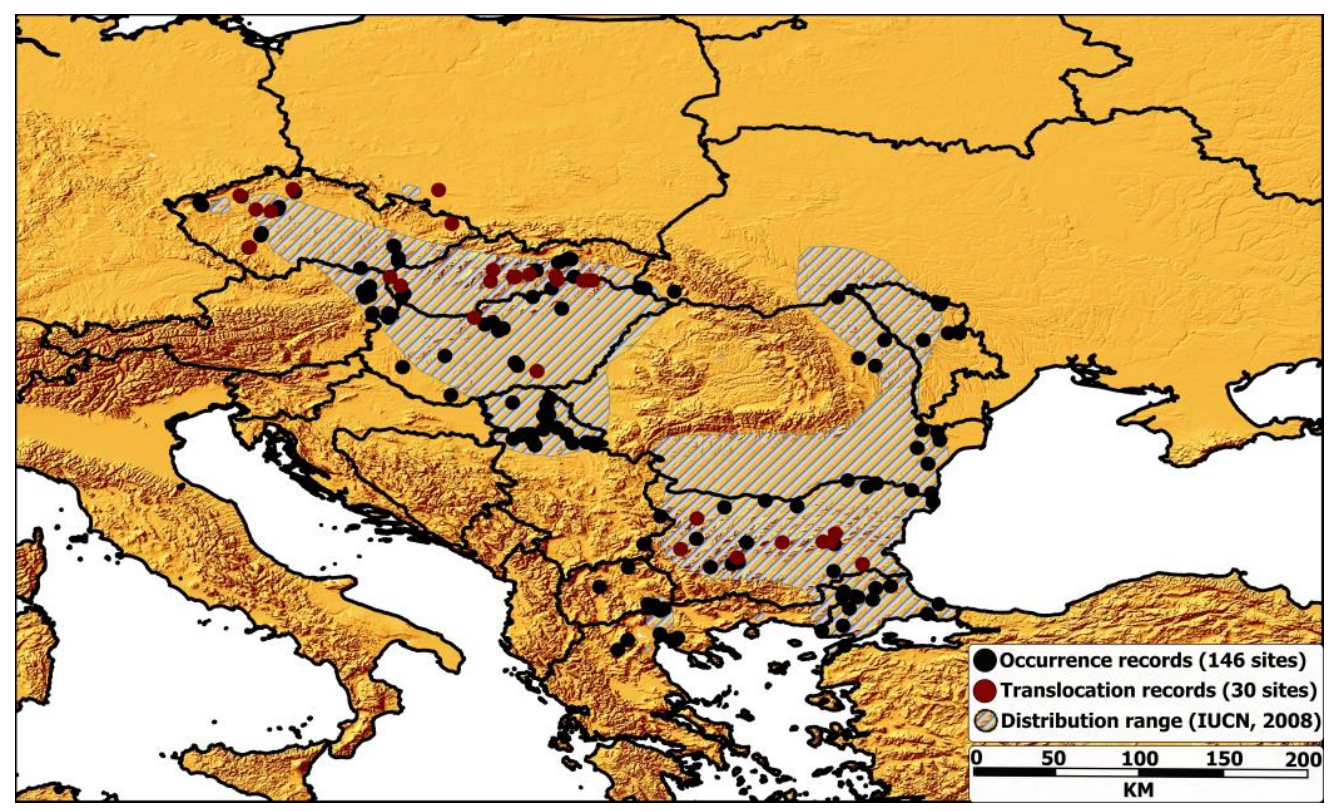

Figure 1. Map of known occurrence and translocation records of the European ground squirrel.

\subsection{Bioclimatic Variables}

19 bioclimatic variables were downloaded from WorldClim Version 1.4 (http://www.worldclim.org/) with a high resolution of $1 \times 1 \mathrm{~km}$ (30 arc seconds) for the past (LGM, approximately $22 \mathrm{kya}$ ), the present data (19502000) and future (average 2070) under the RCP 4.5 emissions scenario) (Hijmans et al., 2005). LGM data was based on two Global Climate Models (CCSM4: The Community Climate System Model and MIROC-ESM: The model for Interdisciplinary Research on Climate). Future data was also based on the above Global Climate Models with only presentative concentration pathways (RCP 4.5) predicting climate change emission scenarios. The downloaded file format was GeoTIFF. All these variables were masked to include only $09^{\circ}$ to $37^{\circ} \mathrm{E}$ and $37^{\circ}$ to $58^{\circ} \mathrm{N}$. Variables which were highly correlated with each other were removed using Pearson correlation coefficients ( $r>0.85$ ) by the SDM toolbox, version 2.4 (Brown, 2014; Brown, Bennett, \& French, 2017) to eliminate multicollinear variables, which can lead to overfitting problems (Dormann et al., 2013; Feng et al., 2019). GeoTIFF raster files were converted to ASCII format using SDM toolbox in ArcGIS version 10.2 (https://www.esri.com). Other file conversions and data processing was conducted using ArcGIS (https://www.esri.com) and DIVA-GIS software. Consequently, a dataset including twelve bioclimatic variables was selected to reveal the niche modeling of the European ground squirrel. MaxEnt version 3.4.1 (Phillips et al., 2006; 2017 a,b) was used for calculating the average of the area under the receiver operator curve (AUC), as well as for assessing the contribution of the environmental variables. In addition, Jack-knife testing was used to assesses the contribution of each environmental variable to the model. MaxEnt settings were logistic output format, 10 random replicate analyses with cross-validation method, minimum training presence threshold, random seed and fade by clamping subsets; all other options were left on default. The AUC is widely used to estimate the predictive accuracy of the developed model (Hanley \& Mcneil, 1982). The AUC 
has values that typically range from 0.5 to 1 , where 1 indicates high performance while 0.5 indicates low performance (Luoto et al., 2005; Elith et al., 2006). If the AUC values are more than 0.80, the constructed model is applicable (Swets, 1988) but if these are less than 0.5, then the model fits worse than a random one (Engler, Guisan, \& Rechsteiner, 2004). The AUC values with 10 replicate runs were calculated separately for the northern lineage, the southern lineage, and the combined data.

\section{Results and Discussion}

The average test AUC values of the constructed model with 10 replicate runs based on default setting in MaxEnt software showed high accuracy in all distribution areas of $S$. citellus. All AUC values detected in this study were higher than 0.80 , indicating that the model was reliable. These values are shown in Table 1 . The 12 bioclimatic variables predicting the present potential distribution of S. citellus are given in Table 2 together with their contribution values. The results of the Jack-knife test supported the MaxEnt results for whole species' range, northern lineage and southern lineage (Supplementary material, Figure S1-3).

Table 1

AUC values and standard deviation for whole species' distribution and sublineage's distribution models

\begin{tabular}{lll}
\hline Model & AUC & AUC stdv. \\
\hline northern lineage & 0.944 & 0.005 \\
southern lineage & 0.981 & 0.007 \\
whole species' range & 0.934 & 0.008 \\
\hline
\end{tabular}

Table 2

Percentage contribution $(\mathrm{Pc})$ and permutation importance $(\mathrm{Pi})$ values of bioclimatic variables used for predicting the present potential distribution of $S$. citellus

\begin{tabular}{|c|c|c|c|c|c|c|}
\hline \multirow[t]{2}{*}{ Bioclimatic variable } & \multicolumn{2}{|c|}{$\begin{array}{l}\text { Northern line- } \\
\text { age }\end{array}$} & \multicolumn{2}{|c|}{$\begin{array}{l}\text { Southern line- } \\
\text { age }\end{array}$} & \multicolumn{2}{|c|}{$\begin{array}{l}\text { Combined } \\
\text { data }\end{array}$} \\
\hline & Pc $(\%)$ & $\mathrm{Pi}(\%)$ & Pc $(\%)$ & $\mathrm{Pi}(\%)$ & Pc $(\%)$ & $\mathrm{Pi}(\%)$ \\
\hline Annual mean temperature (Bio 1) & 0.0 & 0.5 & 0.2 & 0.0 & 0.6 & 0.2 \\
\hline Mean diurnal range (Bio 2) & 27 & 35.8 & 2.1 & 0.1 & 28.4 & 24.4 \\
\hline Temperature annual range (Bio 7) & 10.6 & 17 & 10.1 & 3.0 & 9.8 & 15.5 \\
\hline Mean temperature of wettest quarter (Bio 8) & 20.6 & 6.3 & 6.0 & 0.4 & 10.9 & 4.3 \\
\hline Mean temperature of driest quarter (Bio 9) & 18.6 & 2.9 & 33.5 & 0.4 & 8.8 & 3.7 \\
\hline $\begin{array}{l}\text { Mean temperature of warmest quarter (Bio } \\
\text { 10) }\end{array}$ & 2.1 & 5.2 & 6.8 & 3.5 & 4.3 & 8.9 \\
\hline Mean temperature of coldest quarter (Bio 11) & 7.7 & 1.4 & 11.2 & 2.5 & 13.6 & 4.3 \\
\hline Annual precipitation (Bio 12) & 1.7 & 1.3 & 1.8 & 1.6 & 11.2 & 10.7 \\
\hline Precipitation of wettest month (Bio 13) & 0.5 & 0.5 & 6.4 & 1.8 & 1.0 & 2.0 \\
\hline Precipitation of driest quarter (Bio 17) & 1.0 & 5.3 & 12.2 & 5.2 & 6.6 & 7.9 \\
\hline Precipitation of warmest quarter (Bio 18) & 4.8 & 9.3 & 9.3 & 80.8 & 0.9 & 9.3 \\
\hline Precipitation of coldest quarter (Bio 19) & 5.3 & 14.4 & 0.5 & 0.7 & 3.9 & 8.9 \\
\hline
\end{tabular}

Although habitat information and ecology of the species was extensively researched in previous studies (Váczi \& Altbäcker, 1999; Hoffmann et al., 2003; Kryštufek \& Vohralík, 2005; Özkurt et al., 2005; Matějů et al., 2008; Janderková et al., 2011; Ramos-Lara et al., 2014), there has not been a clear distinction between the lineages. In contrast to previous studies, this study aimed to determine the particular niche requirements for each of the lineages based on bioclimatic data. The raw output of the MaxEnt, which is a continuous prediction 
of environmental variables of certain geographical locations, was completed for S. citellus for three different time periods (the LGM, the present, and the future). The MaxEnt prediction for the present period (Figure 2A, Figure 2B and Figure 2C) nearly matched with the known geographical distribution of the European ground squirrel, suggesting that the distribution is probably closely linked to climatic conditions. The present period analysis also showed that the known geographical distribution of the European ground squirrel highly overlaps with previous studies (Kryštufek, 1999; Hoffmann et al., 2003; Wilson \& Reeder, 2005; Gündüz et al., 2007; Coroiu et al., 2008, Kryštufek et al., 2009; Matějů et al., 2010; Říčanová et al., 2011; 2013; Tiryaki, 2015). However, MaxEnt results indicate the presence of other suitable habitats, particularly in Macedonia and western Greece. It seems that there are still localities waiting to be discovered for $S$. citellus. It is also known that there are no populations of S. citellus among climatically suitable areas including Poland, Germany, the Italian peninsula, the Crimean Peninsula, and the north-western Anatolia.

For the present period, the highest bioclimatic parameter (the percentage contribution or permutation importance) for the northern lineage and the whole species' range were the mean diurnal range (Bio 2). Bio 2 can help provide information pertaining to the relevance of temperature fluctuation for different species (O'Donnell \& Ignizio, 2012). The value of this parameter can well reflect the climatic characteristics of a geographic area. If the mean diurnal range is relatively large, it implies that there are relatively high temperature and powerful sunlight during the day in region. The high temperature and the powerful light is conducive to plant photosynthesis and productivity thereby affecting life characteristics such as body mass, reproductive success, and survival of ground-dwelling squirrels (Van Horne, 2003). Also, the two parameters for the southern lineage were the mean temperature of the driest quarter (Bio 9) and the precipitation of warmest quarter (Bio 18). Bio 9 and Bio 18 provide mean temperatures and total precipitation during the driest and warmest three months of the year, which can be useful for examining how such environmental factors may affect the seasonal distribution of the species. Here, two parameters imply the summer temperature and precipitation which contribute to plant productivity and therefore to the nutrition of the species. These results also indicate that the southern lineage prefers arid and dry areas. Moreover, the northern lineage prefers to be present in areas where 'annual mean temperature' is between $5.49-11.89^{\circ} \mathrm{C}$ (approximately $9.74^{\circ} \mathrm{C}$ ), and 'annual precipitation' is between $428-847 \mathrm{~mm}$ (approximately $597 \mathrm{~mm}$ ). In contrast, the southern lineage prefers to be present in areas where 'annual mean temperature' is between $10.68-16.14^{\circ} \mathrm{C}$ (approximately $13.12^{\circ} \mathrm{C}$ ), and 'annual precipitation' is between $438-703 \mathrm{~mm}$ (approximately $573 \mathrm{~mm}$ ). These results support that the northern and southern lineages have adapted to different climatic conditions. This information is a good criterion in selecting suitable areas for translocation studies such as reinforcement and reintroduction. Thus, this study will help researchers to determine the areas where action plans and conservation project can be implemented to ensure the continued existence of the species.
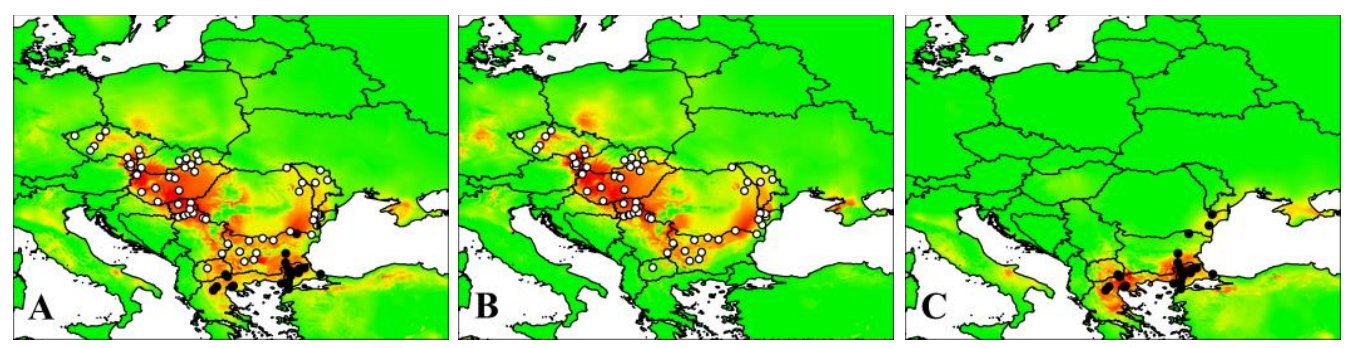

Figure 2. The MaxEnt modeling prediction for the present period (A. combined data, B. northern lineage, C. southern lineage). The open circle shows the occurrence records of the northern lineage, and the closed circle shows the occurrence records of the southern lineage

The combined data shows a potential distribution area between the latitudes of $39^{\circ}$ to $53^{\circ} \mathrm{N}$, and longitudes of $13^{\circ}$ to $30^{\circ} \mathrm{E}$ throughout Europe (Figure 2A). The MaxEnt results also show that the northern lineage has a 
potential distribution area between the latitudes of $41^{\circ}$ to $53^{\circ} \mathrm{N}$, and longitudes of $11^{\circ}$ to $3^{\circ} \mathrm{E}$ in middle Europe (Figure 2B), whereas the southern lineage has a potential distribution area between the latitudes of $39^{\circ}$ to $46^{\circ} \mathrm{N}$, and longitudes of $21^{\circ}$ to $29^{\circ} \mathrm{E}$ in the Balkan region (Figure 2C) under the present climatic conditions. However, the distribution map provided by the IUCN shows that $S$. citellus is distributed between the latitudes of $40^{\circ}$ to $51^{\circ} \mathrm{N}$, and longitudes of $13^{\circ}$ to $29^{\circ} \mathrm{E}$ in Europe. That is, the IUCN coordinates are slightly different from predictions from this study. The results show that the potentially suitable climatic distribution of two $S$. citellus lineages is likely to expand under present climate scenarios, indicating that more suitable habitats will be available for the introduction and reintroduction of the species. These results are consistent with previous studies (Gür, 2013; Gür et al., 2017; Stojak et al., 2019). Nevertheless, it should not be ignored that species distributions are affected by complex dynamics (e.g. microclimate, competition, anthropogenic factors) as well as bioclimatic parameters acting on the distribution area.

The boundaries of the distribution of suitable geographic areas for S. citellus throughout central Europe and the Balkans, suggested by CCSM and MIROC paleoclimatic models, cover a more obvious wide area compared to the present period. This area is particularly noticeable in regions including Germany, the Czech Republic, and Romania. The MIROC model predicts (Figure 3A.2 and Figure 3B.2) more areas to be suitable than the CCSM model (Figure 3A.1 and Figure 3B.1) for the combined data and the northern lineage, but does not predict the same for the southern lineage (Figure 3C.2). Similarly, the western coast of the Black Sea is not predicted as a suitable area for the geographic distribution of the southern lineage, especially in the CCSM model (Figure 3C.1). Additionally, both models show that the northern lineage extended almost to the central regions of Germany, but did not reach Poland. These results are similar to those of Musil (1985) who suggest that the glacial periods were wider than the present interglacial period, and support "cryptic northern refugia" hypothesis for temperate species.
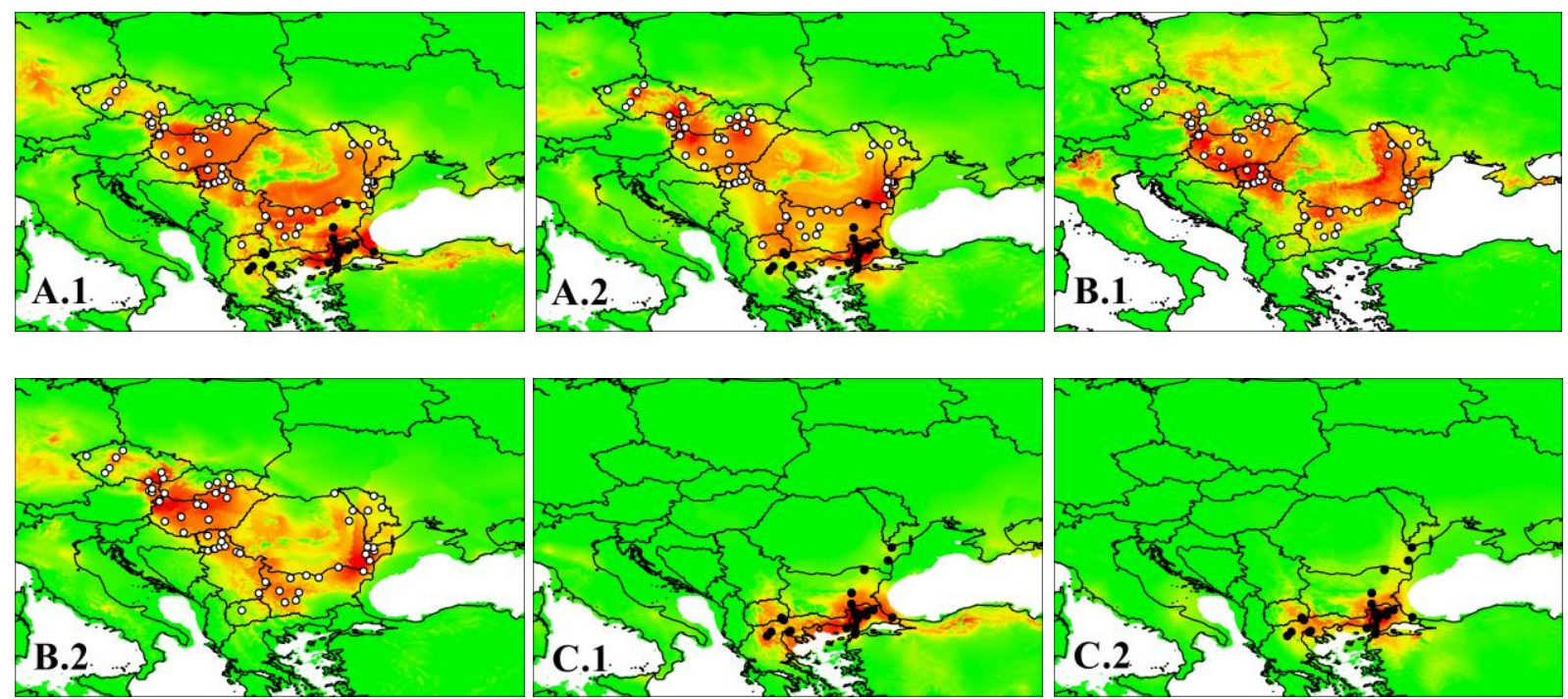

Figure 3. The MaxEnt modeling prediction for the LGM period (A.1. combined data with CCSM model, A.2. combined data with MIROC model, B.1. northern lineage with CCSM model, B.2. northern lineage with MIROC model, C.1. southern lineage with CCSM model, C.2. southern lineage with MIROC model.

MaxEnt predictions suggest two hot spots for the northern lineage at the Pannonian basin and the south-eastern part of the Carpathian Mountains. These regions probably refer to the most extensive suitable habitat areas during the LGM period (Figure 3B.1 and Figure 3B.2). The area around the Carpathian Mountains provided somewhat more temperate climatic conditions than the northern latitudes and formed two refuge areas for the northern lineage. These regions also contain unique fauna and flora elements today (Stewart \& Lister, 2001; Stojak \& Tarnowska, 2019). On the other hand, MaxEnt shows that the southern lineage occupies a single 
hotpoint area around Bulgaria and European Turkey (Figure 3C.1 and 3C.2). This region includes the lowland Thrace, Rhodopes and Istranca Mountains and, also has many indigenous plant and animal species today (Petrova \& Vladimirov, 2010; Valchovski \& Misirlığlu, 2017; Kryštufek et al., 2018). Moreover, these regions were also indicated as ancestral areas for the origin of the S. citellus lineages identified by Řícănová et al. (2013).

Interestingly, even though central Macedonia contained more suitable habitats for the southern lineage compared to the northern lineage, phylogenetic analysis indicated that the Macedonian sublineage was part of the northern lineage in LGM. It appears that this sublineage settled in this region much earlier than the southern lineage. This inference confirmed the molecular clock hypothesis that the separation of the sublineage within the northern lineage started between 0.80 and 1.10 million years ago (Ř́icănová et al., 2013). Conversely, north-eastern Bulgaria and south-eastern Romania contained more favorable habitats for the northern lineage compared to the southern lineage in LGM. Presumably, this spectacle suggests that the southern lineage began to settle in these regions immediately after the LGM period. Moreover, the phylogenetic analyses (Ř́cănová et al., 2013) which include samples from this region show that sublineages within the northern lineage furcated approximately 0.45 million years ago, while sublineages within the southern lineage furcated approximately 0.34 million years ago.

The combined data show a potential distribution area between the latitudes of $38^{\circ}$ to $51^{\circ} \mathrm{N}$ and longitudes of $14^{\circ}$ to $30^{\circ} \mathrm{E}$ throughout Europe (Figure 4A.1 and Figure 4A.2). The MaxEnt results also show that the northern lineage will have a potential distribution area between the latitudes of $41^{\circ}$ to $52^{\circ} \mathrm{N}$ and longitudes of $10^{\circ}$ to $29^{\circ} \mathrm{E}$ in central Europe (Figure 4B.1 and Figure 4B.2), and the southern lineage will have a potential distribution area between the latitudes of $38^{\circ}$ to $45^{\circ} \mathrm{N}$ and longitudes of $20^{\circ}$ to $28^{\circ} \mathrm{E}$ in the Balkan region (Figure 4C.1 and Figure 4C.2) under future climatic conditions. According to these results, the future potential distribution density of the northern lineage is likely to have a more fragmented structure compared to today. This indicates that the northern lineage is highly sensitive to the intensity of climate change. Thus, it can be predicted that the number of suitable habitats and local populations will decrease in the next 50 years. While the distribution of the southern lineage with the MIROC model is very similar to the present distribution, the CSSM model points to a different result. The CCSM model predicts a range of expansion in Macedonia and southern Greece compared to the present period. This means that the southern lineage is likely to be more resilient to climate change compared to the northern lineage, but its population trend should constantly be monitored and conservation measures should not be neglected. Therefore, it can be suggested that the conservation programs and action plans for the northern lineage are more urgent and of greater importance.
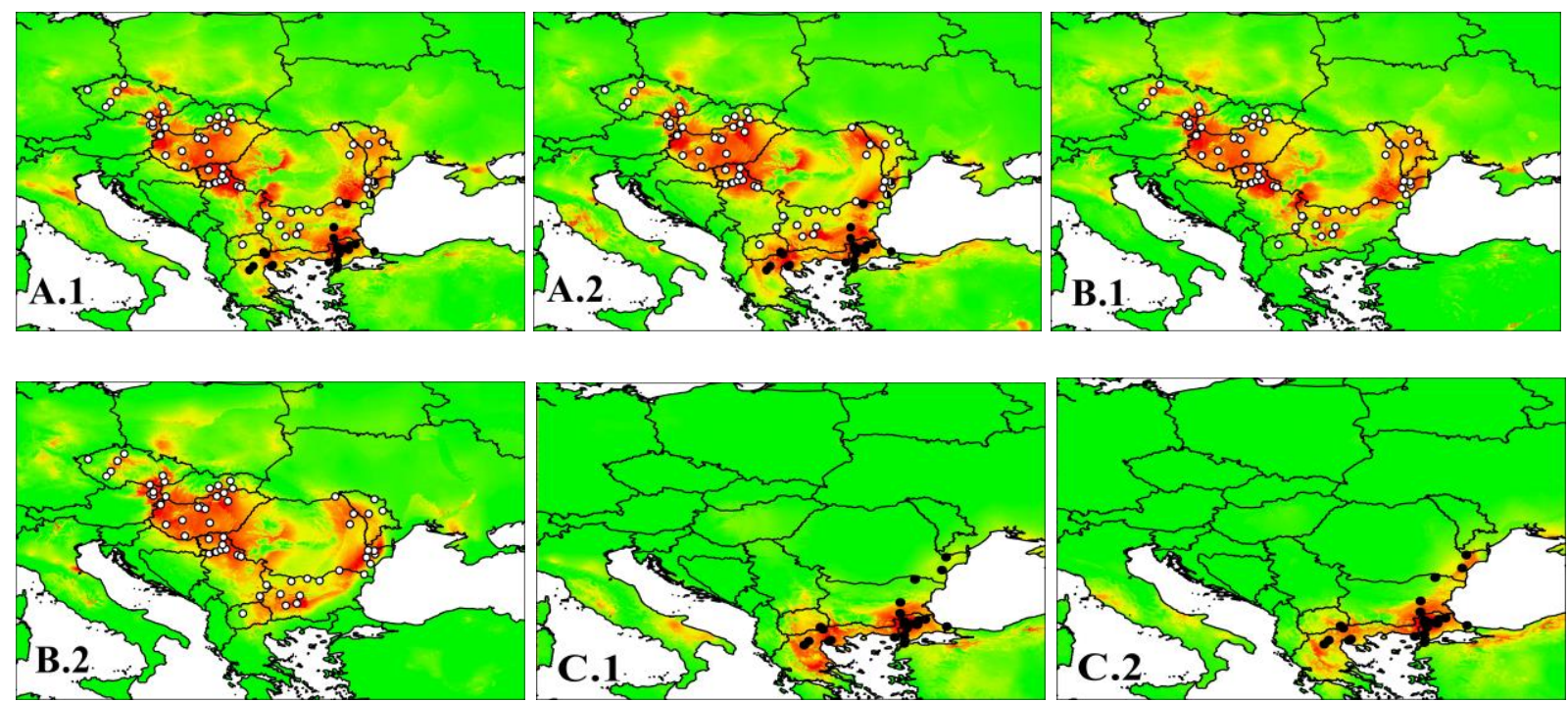
Figure 4. The MaxEnt modeling prediction for the future period (A1. combined data with CCSM model, A2. combined data with MIROC model, B1. northern lineage with CCSM model, B2. northern lineage with MIROC model, C1. southern lineage with CCSM model, C2. southern lineage with MIROC model

\section{Conclusion}

This study estimated the habitat suitability and potential distribution probability of S. citellus in central Europe and the Balkans using the Maximum Entropy Model. MaxEnt fully described the observed present distribution of the European ground squirrel. Accordingly, it predicted which bioclimatic variables were more significant in the geographic distribution of both lineages belonging to the species. Furthermore, this study forecasted the past and future distribution patterns of the two lineages.

The continued survival of the European ground squirrel requires the evaluation of the species as a whole rather than as local populations. The performance of ongoing or completed reinforcement and reintroduction studies (Balaz, Jancova, \& Ambros, 2008; Matějů et al., 2010; 2012; Gedeon et al., 2011; 2012; Löbbová \& Hapl, 2014; Koshev et al., 2019) in European countries is closely linked to climatic change, therefore, the evaluation of climate change scenarios in relation to the potential distribution range of the species will allow researchers to develop possible strategies to increase conservation success. The results of this study indicate that suitable habitats for the two lineages will cover a narrower area compared to the present estimates, so, the regions where introduction and reintroduction studies will be done should not be selected randomly. Moreover, these assessments can be used for management strategies, conservation projects and species action plans.

\section{Acknowledgement}

No financial support was received from any institution or organization in this study.

\section{Author Contributions}

Performed statistical analysis and wrote the paper.

\section{Conflicts of Interest}

The author has no conflict of interest.

\section{References}

Balaz, I., Jancova, A., \& Ambros, M. (2008). Restitution of the European ground squirrel (Spermophilus citellus) in Slovakia. Lynx (Praha), NS 39, 235-240. Retrieved from: https://www.researchgate.net/publication/288338501

Baltag, E.Ş., Zaharia, G., Fasolă, L., \& Constantin, I. (2014). European Ground Squirrel (Mammalia: Rodentia) population from Eastern Romania: density, distribution and threats. European Scientific Journal, 94101. Retrieved from: https://www.researchgate.net/publication/271844575

Barkaszi, Z., \& Zagorodniuk, I. (2018). Living on the edge: distribution patterns of steppe mammals in Transcarpathia (Ukraine). Studia Biologica, 12, 75-94. https://doi.org/10.30970/sbi.1203.573

Benda, P. \& Ivanova, T. (2003). Long-eared bats, Genus Plecotus (Mammalia: Chiroptera), in Bulgaria: a revision of systematic and distributional status. Bulletin of the Natural History Museum, 172, 157-172. Retrieved from: https://www.researchgate.net/publication/228492914

Birks, H.J.B., \& Willis K.J. (2008). Alpines, trees, and refugia in Europe. Plant Ecology \& Diversity, 1, 147160. https://doi.org/10.1080/17550870802349146

Brown, J.L. (2014). SDMtoolbox: a python-based GIS toolkit for landscape genetic, biogeographic, and species distribution model analyses. Methods in Ecology and Evolution, 5(7), 694-700. https://doi.org/10.1111/2041-210X.12200

Brown, J.L., Bennett, J.R., \& French, C.M. (2017). SDMtoolbox 2.0: the next generation Python-based GIS toolkit for landscape genetic, biogeographic, and species distribution model analyses. PeerJ, 5:e4095. 
Coroiu, C., Kryštufek, B., Vohralík, V., \& Zagorodnyuk, I. (2008). Spermophilus citellus. The IUCN Red List $\begin{array}{lllll}\text { of } \quad \text { Threatened } & \text { Species } & \text { 2008: } & \text { e.T20472A92 }\end{array}$ http://dx.doi.org/10.2305/IUCN.UK.2008.RLTS.T20472A9204055.en. Downloaded on 17 October 2019.

Diakou, A. Kapantaidakis, E., \& Youlatos, D. (2015). Endoparasites of the European ground squirrel (Spermophilus citellus) (Rodentia: Sciuridae) in central Macedonia, Greece. Journal of Natural History, 49(58), 359-370. https://doi.org/10.1080/00222933.2013.825025

Dormann, C.F., Elith, J., Bacher, S., Buchman, C., Carl, G., Carré, G., García Marquéz, J.R., Gruber, B., Lafourcade, B., Leitão, P.J., Münkemüller, T., McClean, C., Osborne, P.E., Reineking, B., Schröder, B., Skidmore, A.K., Zurell, D., \& Lautenbach S. (2013). Collinearity: A review of methods to deal with it and a simulation study evaluating their performance. Ecography, 36, 27-46. https://doi.org/10.1111/j.1600-0587.2012.07348.x

Elith, J., Graham, C.H., Anderson, R.P., Dudik, M., Ferrier, S., Guisan, A., Hijmans, R.J., Huettmann, F., Leathwick, J.R., Lehmann, A., Li, J., Lohmann, L.G., Loiselle, B. A., Manion, G., Moritz, C., Nakamura, M., Nakazawa, Y., Overton, J.M., Peterson, A. T., Phillips, S.J., Richardson, K., Scachetti-Pereira, R., Schapire, R.E., Soberon, J., Williams, S., Wisz, M.S., \& Zimmermann, N.E. (2006). Novel methods improve prediction of species' distributions from occurrence data. Ecography, 29, 129-151. https://doi.org/10.1111/j.2006.0906-7590.04596.x

Elith, J., Phillips, S.J., Hastie, T., Dudík, M., Chee, Y.E., \& Yates, C.J. (2011). A statistical explanation of MaxEnt for ecologists. Diversity and Distributions, 17(1), 43-57. https://doi.org/10.1111/j.14724642.2010.00725.x

Engler, R., Guisan, A., \& Rechsteiner, L. (2004). An improved approach for predicting the distribution of rare and endangered species from occurrence and pseudo-absence data. Journal of Applied Ecology, 41, 263 274. https://doi.org/10.1111/j.0021-8901.2004.00881.X

Feng, X., Park, D.S., Liang, Y., Pandey, R., \& Papeş, M. (2019). Collinearity in ecological niche modeling: Confusions and challenges. Ecology and Evolution, 9(18), 10365-10376. https://doi.org/10.1002/ece3.5555

Fortelius, M. (2011). Neogene of the Old World Database of Fossil Mammals. University of Helsinki. Retrieved from: https://researchportal.helsinki.fi/en/equipments/now-new-and-old-worlds-fossil-mammaldatabase

Fourcade, Y., Engler, J.O., Rödder, D., \& Secondi, J. (2014). Mapping species distributions with MAXENT using a geographically biased sample of presence data: a performance assessment of methods for correcting sampling bias. PloS One, 9(5), e97122. https://doi.org/10.1371/journal.pone.00971221

Gedeon, C.I., Váczi, O., Koósz, B., \& Altbäcker, V. (2011). Morning release into artificial burrows with retention caps facilitates success of European ground squirrel (Spermophilus citellus) translocations. European Journal of Wildlife Research, 57(5), 1101-1105. https://doi.org/10.1007/s10344-011-0504-3

Gedeon, C.I., Boross, G., Németh, A., \& Altbäcker, V. (2012). Release site manipulation to favour European ground squirrel Spermophilus citellus translocations: translocation and habitat manipulation. Wildlife Biology, 18(1), 97-104. https://doi.org/10.2981/10-124

Guisan, A., Tingley, R., Baumgartner, J.B., Naujokaitis-Lewis, I., Sutcliffe, P.R., Tulloch, A.I., Regan, T.J., Brotons, L., McDonald-Madden, E., Mantyka-Pringle, C., Martin, T.G., Rhodes, J.R., Maggini, R., Setterfield, S.A., Elith, J., Schwartz M.W., Wintle, B.A., Broennimann, O., Austin M., Ferrier, S., Kearney, M.R., Possingham, H.P., \& Buckley, Y.M. (2013). Predicting species distributions for conservation decisions. Ecology Letters, 16(12), 1424-1435. https://doi.org/10.1111/ele.12189

Gündüz, İ., Jaarola, M., Tez, C., Yeniyurt, C., Polly, P.D., \& Searle, J.B. (2007). Multigenic and morphometric differentiation of ground squirrels (Spermophilus, Scuiridae, Rodentia) in Turkey, with a description of a new species. Molecular Phylogenetics and Evolution, 43, 916-935. https://doi.org/10.1016/j.ympev.2007.02.021 
Gür, H. (2013). The effects of the late Quaternary glacial-interglacial cycles on Anatolian ground squirrels: range expansion during the glacial periods. Biological Journal of the Linnean Society, 109, 19-32. https://doi.org/10.1111/bij.12026

Gür, H., Perktaş, U., \& Gür, M.K. (2017). Do climate-driven altitudinal range shifts explain the intraspecific diversification of a narrow ranging montane mammal, Taurus ground squirrels? Mammal Research, 63(2), 197-211. https://doi.org/10.1007/s13364-017-0347-8

Haberl, W., Kryštufek, B. \& Hoffmann, I.E. (2012). Distribution and assessment of endangered European ground squirrel (Spermophilus citellus gradojevici) populations in south-eastern Macedonia (FYROM). 3rd European Congress of Conservation Biology, Glasgow, Scotland. Retrieved from: https://www.researchgate.net/publication/323322689

Hanley, J.A., \& McNeil, B.J. (1982). The meaning and use of the area under a receiver operating characteristic (ROC) curve. Radiology, 143, 29-36. https://doi.org/10.1148/radiology.143.1.7063747

Harrison, R.G., Bogdanowicz, S.M., Hoffmann, R.S., Yensen, E., Sherman, P.W. (2003). Phylogeny and evolutionary history of the ground squirrel (Rodentia: Marmotinae). Journal of Mammalian Evolution, 10, 249-276. https://doi.org/10.1023/B:JOMM.0000015105.96065.f0

Hewitt, G. (2000). The genetic legacy of the Quaternary ice ages. Nature, 405(6789), 907-913. https://doi.org/10.1038/35016000

Hewitt, G.M. (1996). Some genetic consequences of ice ages, and their role in divergence and speciation. Biological Journal of the Linnean Society, 58, 247-276. https://doi.org/10.1006/bijl.1996.0035

Hijmans, R.J., Cameron, S.E., Parra, J.L., \& Albert, D.L. (2005). Very high resolution interpolated climate surfaces for global land areas. International Journal of Climatology, 25, 1965-1978. http://doi.wiley.com/10.1002/joc.1276

Hijmans, R.J., \& Graham, C.H. (2006). Testing the ability of climate envelope models to predict the effect of climate change on species distributions. Global Change Biology, 12, 2272-2281. https://doi.org/10.1111/j.1365-2486.2006.01256.x

Hoffmann, I.E., Millesi, E., Huber, S., Everts, L.G., Dittami, J. P. (2003). Population Dynamics of European Ground Squirrels (Spermophilus citellus) in a Suburban Area. Journal of Mammalogy, 84(2), 615-626. https://doi.org/10.1644/1545-1542(2003)084<0615:PDOEGS>2.0.CO;2

Hoffmann, I.E., Turrini, T., \& Brenner, M. (2008). Do European ground squirrels in Austria adjust their life history to anthropogenic influence? Lynx (Praha), 39(2), 241-250. Retrieved from: https://www.researchgate.net/publication/259475994

Hulová, Š., \& Sedláček, F. (2008). Population genetic structure of the European ground squirrel in the Czech Republic. Conservation Genetics, 9, 615-625. https://doi.org/10.1007/s10592-007-9378-z.

Janák, M., Marhoul, P., \& Matějů, J. (2013). Action Plan for the Conservation of the European Ground Squirrel Spermophilus citellus in the European Union. Retrieved from: https://ec.europa.eu/environment/nature/conservation/species/action_plans

Janderková, J., Matějů, J., Schnitzerová, P., Petruš, J., Sedláček, J., \& Uhlíková, J. (2011). Soil characteristics at Spermophilus citellus localities in the Czech Republic (Rodentia, Sciuridae). Lynx, 42, 99-111. Retrieved from: https://publikace.nm.cz/file/722e0fe453a88e35d055598c2b0f6c48/16927/99-111_Janderkov\%C3\%A1.pdf

Katona, K., Váczi. O., \& Altbäcker V. (2002). Topographic distribution and daily activity of the European ground squirrel population in Bugacpuszta, Hungary. Acta Theriologica, 47(1), 45-54. https://doi.org/10.1007/BF03193565

Koshev, Y.S. (2009). Distribution, isolation and recent status of European ground squirrel (Spermophilus citellus L.) in Pazardzhik district, Bulgaria. Annual of Shumen University "Konstantin Preslavsky", Faculty of Natural Sciences, Vol. XIX B6: 97-109. ISSN: 1311-834X. https://www.researchgate.net/publication/258452659 
Koshev, Y.S., Kachamakova, M., Arangelov, S., \& Ragyov, D. (2019). Translocations of European ground squirrel (Spermophilus citellus) along altitudinal gradient in Bulgaria - an overview. Nature Conservation, 35, 63-95. https://doi.org/10.3897/natureconservation.35.30911

Kryštufek, B. (1999). Spermophilus citellus (Linnaeus, 1766). 190-191 pp. In the atlas of European mammals (Mitchell-Jones A. J.ed.). Academic Press London, United Kingdom.

Kryštufek, B., \& Vohralík, V. (2005). Mammals of Turkey and Cyprus, Vol. 2: Rodentia I: Sciuridae, Dipodidae, Gliridae, Arvicolinae, Annales Majora Koper, Slovenia.

Kryštufek, B., Bryja, J., \& Buzan, E.V. (2009). Mitochondrial phylogeography of the European ground squirrel, Spermophilus citellus, yields evidence on refugia for steppic taxa in the southern Balkans. Heredity, 103, 129-135. https://doi.org/10.1038/hdy.2009.41

Kryštufek, B., Nedyalkov, Nedko., Astrin, J.J., \& Hutterer, R. (2018). News from the Balkan refugium: Thrace has an endemic mole species (Mammalia: Talpidae). Bonn Zoological Bulletin, 67(1), 41-57. Retrieved from: https://www.researchgate.net/publication/328019990

Kurten, B. (1968). Pleistocene Mammals of Europe. Weidenfeld \& Nicolson, London.

Ramos-Lara, N., Koprowski, J.L., Kryštufek, B., Hoffmann, I.E. (2014). Spermophilus citellus (Rodentia: Sciuridae). Mammalian Species, 46(913), 71-87. https://doi.org/10.1644/913.1

Löbbová, D., \& Hapl, E. (2014). Conservation of European ground squirrel (Mammalia: Rodentia) in Slovakia: Results of current reintroduction programme. Slovak Raptor Journal, 8, 105-112. https://doi.org/10.2478/srj-2014-0012

Luoto, M., Pöyry, J., Heikkinen, R.K., \& Saarinen, K. (2005). Uncertainty of bioclimate envelope models based on geographical distribution of species. Global Ecology and Biogeography, 14, 575-84. https://doi.org/10.1111/j.1466-822X.2005.00186.x

Matěju, J., Nová, P., Uhlíková, J., Hulová, Š., \& Cepáková, E., (2008). Distribution of the European ground squirrel (Spermophilus citellus) in the Czech Republic in 2002-2008. Lynx, 39, 277-294. Retrieved from:

https://publikace.nm.cz/file/128af2d7b6eae61b13dec15d7a2b9ec2/16133/Mat\%C4\%9Bj\%C5\%AF20081ynx2.pdf

Matějů, J., Hulová, Š., Nová, P., Cepáková, E., Marhoul, P., \& Uhlíková, J. (2010). Action plan for the European Ground Squirrel (Spermophilus citellus) in the Czech Republic. Charles University and Agency for Nature and Landscape Protection of the Czech Republic, Prague. Retrieved from: https://ec.europa.eu/environment/nature/conservation/species/action_plans

Matějů, J., Říčanová, Š., Poláková, S., Ambros, M., Kala, B., Matějů, K., \& Kratochvíl L. (2012). Method of releasing and number of animals are determinants for the success of European ground squirrel (Spermophilus citellus) reintroductions. European Journal of Wildlife Research, 58(2), 473-482. https://doi.org/10.1007/s10344-011-0597-8

Mráz, P., \& Ronikier, M. (2016). Biogeography of the Carpathians: evolutionary and spatial facets of biodiversity. Biological Journal of the Linnean Society, 119, 528-559. https://doi.org/10.1111/bij.12918

Musil, R. (1985). Paleobiography of terrestrial communities in Europe during the last glacial. Acta Musei Nationalis Pragae XLI B, no. 1-2: 25-56. Retrieved from: http://fi.nm.cz/en/archive/

Pearson, R.G., Thuiller, W., Araújo, M.B., Martinez-Meyer, E., Brotons, L., Mcclean, C., Miles, L., Segurado, P., Dawson, T.P., \& Lees, D.C. (2006). Model based uncertainty in species range prediction. Journal of Biogeography, 33, 1704-1711. https://doi.org/10.1111/j.1365-2699.2006.01460.x

Peltier, W.R. (1994). Ice Age Paleotopography. Science 265(5169), 195-201. https://doi.org/10.1126/science.265.5169.195 https://doi.org/10.1038/416626a

Peterson, A.T., Ortega-Huerta, M.A., Bartley, J., Sanchez-Cordero, V., Soberon, J., Buddemeier, R.H., \& Stockwell, D.R. (2002). Future projections for Mexican faunas under global climate change scenarios. Nature, 416(6881), 626-629. https://doi.org/10.1038/416626a

Petrova, A., \& Vladimirov, V. (2010). Balkan endemics in the Bulgarian flora. Phytologia Balcanica, 16(2), 293-311. Retrieved from: https://www.researchgate.net/publication/268180051 
Phillips, S.J., Dudík, M., \& Schapire, R.E. (2004). A maximum entropy approach to species distribution modeling. In: Proceedings of the 21st International Conference on Machine Learning. NewYork, NY: ACM Press, 655-662. Retrieved from: https://www.researchgate.net/publication/221345128

Phillips, S.J., Anderson, R.P., \& Schapire, R.E. (2006). Maximum entropy modeling of species geographic distributions. Ecological Modelling, 190, 231-259. https://doi.org/10.1016/j.ecolmodel.2005.03.026

Phillips, S.J., Dudík, M., \& Schapire, R.E. (2017a). MaxEnt software for modeling species niches and distributions. Version 3.4.1. Available from: https://biodiversityinformatics.amnh.org/open_source/maxent

Phillips, S.J., Anderson, R.P., Dudík, M., Schapire, R.E., \& Blair, M.E. (2017b). Opening the black box: an open-source release of Maxent. Ecography, 40(7), 887-893. https://doi.org/10.1111/ecog.03049

Pollard, D., \& Thompson, S.L. (1997). Climate and ice-sheet mass balance at the last glacial maximum from the GENESIS version 2 global climate model. Quaternary Science Reviews, 16, 841-863. https://doi.org/10.1016/S0277-3791(96)00115-1

Popova, L.V., Maul, L.C., Zagorodniuk, I.V., Veklych, Y.M., Shydlovskiy, P.S., Pogodina, N.V., Bondar K.M., Strukova, T.V., \& Parfitt, S.A. (2019). Good fences make good neighbours': Concepts and records of range dynamics in ground squirrels and geographical barriers in the Pleistocene of the Circum Black Sea area. Quaternary International, 509, 103-120. https://doi.org/10.1016/j.quaint.2018.03.023

O’Donnell, M.S., \& Ignizio, D.A. (2012). Bioclimatic predictors for supporting ecological applications in the conterminous United States: U.S. Geological Survey Data Series 691, 10. Available from: https://pubs.usgs.gov/ds/691

Qiao, H., Escobar, L.E., \& Peterson, T. (2017). Accessible areas in ecological niche comparisons of invasive species: Recognized but still overlooked. Scientific Reports, 7(1), 1213. https://doi.org/10.1038/s41598017-01313-2

Özkurt, Ş., Yiğit, N., Çolak, E., Sözen, M., Gharakheloo M.M. (2005). Observations on the ecology, reproduction and behavior of Spermophilus Bennett, 1835 (Mammalia: Rodentia) in Turkey. Turkish Journal of Zoology, 29(1), 91-99. Retrieved from: https://www.researchgate.net/publication/260081812

Říčanová, S., Bryja, J., Cosson, J.F., Gedeon, C., Choleva, L., Ambros, M., \& Sedláček, F. (2011). Depleted genetic variation of the European ground squirrel in Central Europe in both microsatellites and the major histocompatibility complex gene: implication for conservation. Conservation Genetics, 12, 1115-1129. https://doi.org/10.1007/s10592-011-0213-1

Říčanová, Š., Koshev, Y., Říčan, O., Ćosić, N., Ćirović, D., Sedláček, F., \& Bryja, J. (2013). Multilocus phylogeography of the European ground squirrel: cryptic interglacial refugia of continental climate in Europe. Molecular Ecology, 22(16), 4256-4269. https://doi.org/10.1111/mec.12382

Santel, W., von Koenigswald, W. (1998). Preliminary report on themiddle Pleistocene small mammal fauna from Yarimburgaz Cave in Turkish Thrace. Eiszeitalter \& Gegenwart, 48, 162-169. https://doi.org/10.3285/eg.48.1.14, 1998 10.3390/genes8110292

Savić, I., Ćirović, D., \& Bugarski-Stanojević, V. (2017). Exceptional Chromosomal Evolution and Cryptic Speciation of Blind Mole Rats Nannospalax leucodon (Spalacinae, Rodentia) from South-Eastern Europe. Genes, 8(11), 292. https://doi.org/10.3390/genes8110292

Stewart, J.R., \& Lister, A. M. (2001). Cryptic northern refugia and the origins of the modern biota. Trends in Ecology \& Evolution, 16(11), 608-613. https://doi.org/10.1016/S0169-5347(01)02338-2

Stewart, JR., Lister, A.M, Barnes, I., \& Dalén, L. (2010). Refugia revisited: individualistic responses of species in space and time. Proceedings Biological Sciences, 277(1682), 661-671. https://doi.org/10.1098/rspb.2009.1272

Stojak, J., \& Tarnowska, E. (2019). Polish suture zone as the goblet of truth in post-glacial history of mammals in Europe. Mammalian Research, 64, 463-475. https://doi.org/10.1007/s13364-019-00433-6

Stojak, J., Borowik, T., Górny, M., McDevitt, A.D., \& Wójcik J.M. (2019). Climatic influences on the genetic structure and distribution of the common vole and field vole in Europe. Mammal Research, 64, 19-29. https://doi.org/10.1007/s13364-018-0395-8 
Swets, J. (1988). Measuring the accuracy of diagnostic systems. Science, 240(4857), 1285-1293. https://doi.org/10.1126/science.3287615

Tiryaki, D. (2015). Türkiye Spermophilus Cuvier, 1825 (Mammalia: Rodentia) türlerinin filocoğrafyası, filogenisi ve soy hattı sinırlarının detaylı incelenmesi, Doktora Tezi, Ondokuz Mayıs Üniversitesi, Fen Bilimleri Enstitüsü. Samsun, Turkey. Retrieved from: http://libra.omu.edu.tr/tezler/87349.pdf

Tzvetkov, J., \& Koshev, Y. (2016). GIS habitat model of potential distribution of European ground squirrel (Spermophilus citellus) in Bulgaria. Belgrade, Serbia, 6th European Ground Squirrel Meeting. https://doi.org/10.13140/RG.2.2.26177.97124

Váczi, O., \& Altbäcker, V. (1999). Füves repülőterek ürgeállományának felmérése. Természetvédelmi Közlemények, 8, 205-214. Retrieved from: https://adtplus.arcanum.hu/hu/view/TermeszetvedelmiKozlemenyek_08

Valchovski, H., \& Misırlığlu İ.M. (2017). Review of earthworm (Clitellata: Lumbricidae, Criodrilidae, Acanthodrilidae) biodiversity of thrace in Bulgaria, Turkey and Greece. Sakarya Üniversitesi Fen Bilimleri Enstitüsü Dergisi, 21(6), 1325-1330. https://doi.org/10.16984/saufenbilder.306021

Van Horne, B. (2003). Conservation of ground squirrels. In: Wolff JO, Sherman PW, eds. Rodent societies: an ecological and evolutionary perspective. Chicago, IL: University of Chicago Press, 463-471.

Wilson, D.E., \& Reeder, D.M. (2005). Mammal Species of the World. A Taxonomic and Geographic Reference. 3rd ed. Johns Hopkins University Press, Baltimore.

Wisz, M.S., Hijmans, R.J., Li, J., Peterson, A.T., Graham, C.H., \& Guisan, A. (2008). Effects of sample size on the performance of species distribution models. Diversity and Distributions, 14(5), 763-773. https://doi.org/10.1111/j.1472-4642.2008.00482.x

Youlatos, D., Boutsis Y., Pantis, J.D. \& Hadjicharalambous, H. (2007). Activity patterns of European ground squirrels (Spermophilus citellus) in a cultivated field in northern Greece. Mammalia, 71(4), 183-186. https://doi.org/10.1515/MAMM.2007.030

Zaharia, G., Petrencu, L., \& Baltag E.S. (2016). Site selection of European ground squirrels (Spermophilus citellus) in Eastern Romania and how they are influenced by climate, relief, and vegetation. Turkish Journal of Zoology, 40, 917-924. https://doi.org/10.3906/zoo-1505-28 